\title{
"The relationship between employee well-being and organizational trust in the context of sustainable human resource management"
}

\begin{tabular}{|c|c|}
\hline AUTHORS & $\begin{array}{l}\text { Vaida Jaskeviciute } \\
\text { Asta Stankeviciene } \\
\text { Danuta Diskiene } \\
\text { Julija Savicke }\end{array}$ \\
\hline ARTICLE INFO & $\begin{array}{l}\text { Vaida Jaskeviciute, Asta Stankeviciene, Danuta Diskiene and Julija Savicke } \\
(2021) \text {. The relationship between employee well-being and organizational trust in } \\
\text { the context of sustainable human resource management. Problems and } \\
\text { Perspectives in Management, 19(2), 118-131. doi:10.21511/ppm.19(2).2021.10 }\end{array}$ \\
\hline DOI & http://dx.doi.org/10.21511/ppm.19(2).2021.10 \\
\hline RELEASED ON & Friday, 21 May 2021 \\
\hline RECEIVED ON & Saturday, 06 March 2021 \\
\hline \multirow[t]{2}{*}{ ACCEPTED ON } & Monday, 17 May 2021 \\
\hline & $(\mathrm{sc})$ EY $^{\mathrm{E}}$ \\
\hline LICENSE & $\begin{array}{l}\text { This work is licensed under a Creative Commons Attribution } 4.0 \text { International } \\
\text { License }\end{array}$ \\
\hline JOURNAL & "Problems and Perspectives in Management" \\
\hline ISSN PRINT & $1727-7051$ \\
\hline ISSN ONLINE & $1810-5467$ \\
\hline PUBLISHER & LLC "Consulting Publishing Company "Business Perspectives" \\
\hline FOUNDER & LLC "Consulting Publishing Company "Business Perspectives" \\
\hline
\end{tabular}

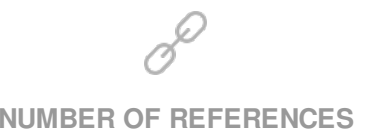

82

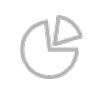

NUMBER OF FIGURES

1

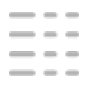

NUMBER OF TABLES

2

(C) The author(s) 2021. This publication is an open access article. 


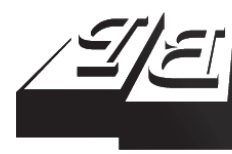

BUSINESS PERSPECTIVES

(O)

LLC "CPC "Business Perspectives" Hryhorii Skovoroda lane, 10, Sumy, 40022, Ukraine www.businessperspectives.org
Received on: $6^{\text {th }}$ of March, 2021 Accepted on: 17 $7^{\text {th }}$ of May, 2021 Published on: $21^{\text {st }}$ of May, 2021

(C) Vaida Jaskeviciute, Asta Stankeviciene, Danuta Diskiene, Julija Savicke, 2021

Vaida Jaskeviciute, Ph.D. Student, Faculty of Economics and Business Administration, Vilnius University Vilnius, Lithuania. (Corresponding author)

Asta Stankeviciene, Ph.D., Associate Professor, Faculty of Economics and Business Administration, Vilnius University, Vilnius, Lithuania.

Danuta Diskiene, Ph.D. habil. Professor, Faculty of Economics and Business Administration, Vilnius University, Vilnius, Lithuania.

Julija Savicke, Ph.D., Assistant Professor, Faculty of Economics and Business Administration, Vilnius University, Vilnius, Lithuania.
Vaida Jaskeviciute (Lithuania), Asta Stankeviciene (Lithuania), Danuta Diskiene (Lithuania), Julija Savicke (Lithuania)

\section{THE RELATIONSHIP BETWEEN EMPLOYEE WELL-BEING AND ORGANIZATIONAL TRUST IN THE CONTEXT OF SUSTAINABLE HUMAN RESOURCE MANAGEMENT}

\begin{abstract}
As the impact of the COVID-19 pandemic continues to grow, new challenges in the organizational and business environment emerge, causing the human resource management (HRM) to develop a flexible yet strategic and sustainable response in the face of instability and uncertainty. HRM practices that focus on employees' emotional, psychological, and cognitive states are becoming crucial. The aim of this paper is to disclose the relationship between employee well-being and organizational trust in the context of sustainable HRM. The literature analysis revealed that sustainable HRM practices focused on meeting the needs of employees are particularly significant as they positively influence employee well-being. Furthermore, ensuring employee wellbeing based on sustainable HRM principles leads to increased organizational trust. The results of the analysis proved direct and indirect relationships between employee well-being and organizational trust; however, further research is needed to distinguish the relationship between sustainable human resource management practices and employee well-being, with a mediating role and moderating role of organizational trust.
\end{abstract}

\section{Keywords}

job satisfaction, engagement, trust in co-workers, interpersonal trust, impersonal trust, HRM

\section{JEL Classification I31, I39, J28, M12}

\section{INTRODUCTION}

Changing conditions in organizations' environment related to the economic and social challenges caused by the COVID-19 pandemic have stimulated changes in the attitude of organizations towards human resources. Presently, HR is perceived as one of the most significant assets defining the success of an organization (Tamasevicius et al., 2020; Laužikas, \& Miliūtè, 2020; Prasetyo, \& Kistanti, 2020). Therefore, new challenges for HRM arise, demanding it to be strategic, sustainable, and responsive in the face of unstable organizational and business environments (Boudreau \& Ziskin, 2011; Cleveland et al., 2015; Arbatani et al., 2016; Macke \& Genari, 2019; Malyaretc et al., 2019; Tolstyakova, \& Batyrova, 2020). Therefore, in adapting to contemporary issues, organizations must adhere to the new requirements for the development of sustainability and its integrative parts: employee well-being and organizational trust.

Widely discussed sustainable HRM focuses on the satisfaction of employees' needs and significantly contributes to the positive changes in employee well-being. It is influenced by organizational trust, which is viable for smooth organizational performance, especially nowadays amid the worldwide COVID-19 pandemic. 
As various studies suggest, ensuring employee well-being leads to higher satisfaction with job and personal life; more persistent goal achievement; taking opportunities for continuous improvement and ability to cope with complex situations; maintaining warm, trust-based relationships with other people; and contributing to the effective functioning of the organization in both stable and emergency conditions (Khoreva \& Wechtler, 2018; Guest, 2017; Cooper et al., 2019).

However, it should be noted that in establishing sustainable HRM practices in an organization, organizational trust plays a critical role. Various authors state that organizational trust provides positive consequences to an organization and its employees: employee security, commitment, identification with the organization, and others.

In the context of this paper, the relevance of organizational trust and its relationships with employee well-being contribute to the effective functioning of an organization, creating a positive, trust-based organizational climate and forming sustainable attitudes towards an organization as caring for employees. When an organization recognizes the links between well-being-oriented HRM practices and respect for employees and their talents, encouragement to grow, and development of trust, its employees are more likely to use their potential effectively (Yidong \& Xinxin, 2013).

The aim of this paper is to disclose the relationship between employee well-being and organizational trust in the context of sustainable HRM.

\section{LITERATURE REVIEW}

Scientific discussions regarding employee well-being have begun somewhat long ago when the World Health Organization has defined health as a state of complete physical, mental, and social well-being rather than merely the absence of disease or disability (World Health Organization, 2010). As the concept of health crossed the threshold of a pathogenic approach and established a salutogenic orientation, the need for a well-being paradigm arose. It led to a significant and unquenchable interest in this phenomenon among researchers and practitioners.

The first author of the well-being concept, the American therapist Dunn (1959), based it on a positive approach to health as defined by the WHO (2010), emphasized the physical and spiritual dimensions of well-being, and associated well-being with maximizing an individual's potential. Later, this idea was disclosed by proponents of the eudemonic concept of well-being who disclosed well-being through meaningfulness and self-realization and defined it as a degree of absolute functioning of an individual (Zheng et al., 2015; Guest, 2017).

Eudemonic approach associates well-being (the narrow approach to well-being) with striving to understand a possessed set of psychological characteristics indicative of mental health (Waterman et al., 2010). Widely recognized concepts, such as "personal growth" (Compton et al., 1996), "personal expressiveness" (Waterman et al., 2010), "self-actualization" (Ryan \& Deci, 2001), psychological well-being (Ryff, 1989), and others are used as synonymous to the eudemonic approach to well-being.

Based on the eudemonic approach, Ryff (1989) has enriched the well-being concept by forming a six-dimensional psychological well-being model that includes six positive psychological functioning areas: self-acceptance (positive attitudes towards oneself and one's life), positive relations with others (maintaining warm relationships), autonomy (ability to maintain one's beliefs), environmental mastery (ability to cope with life demands), the purpose in life (possessing purposes), and personal growth (possessing a feeling of self-realization).

Another widely recognized approach to well-being is the hedonic approach (broad approach). Contemporary psychology considers the hedonic approach to well-being and subjective well-being as synonyms. The hedonic approach associates well-being with happiness and defines 
well-being as the pursuit of a pleasant experience and the avoidance of pain. It is the satisfaction or happiness arising from optimal functioning (Guest, 2017; Viot \& Benraiss-Noailles, 2019). Diener et al. (1999) disclosed subjective well-being as a three-component model characterized by the experience of positive and negative emotional encounters and the evaluation of satisfaction with life (Guest, 2017). Negative emotions are usually associated with the avoidance of punishment (negative impact), while positive - with a good feeling (positive impact). Furthermore, empirical studies have shown the advantages of good feeling in increasing employee productivity, and reducing intention to leave the company (Viot \& Benraiss-Noailles, 2019; Bernardi, 2019).

Both above-mentioned approaches to well-being (subjective or hedonic; and psychological or eudemonic) lay the basis for the employee well-being model (Zheng et al., 2015; Zhang et al., 2020). However, different researchers emphasize different aspects of it. Some authors divide employee well-being into psychological, physical, and social (Guest, 2017; Khoreva \& Wechtler, 2018; Cooper et al., 2019; Ponting, 2020), while others decompose it into happiness, health, and relationships (Van De Voorde et al., 2012). It should be noted that the aforementioned well-being dimensions are interrelated and analyzed both together and separately. Studies have revealed a set of factors that help ensuring employee well-being at the organizational level: i.e., ensuring benevolence to employees and work conditions (Viot \& BenraissNoailles, 2019), ethical leadership (Yang, 2014), communication (Sakka \& Ahammad, 2020), satisfaction with compensations and benefits practices (Bilan et al., 2020); at the individual level: i.e. personal abilities (Orsila et al., 2011), social-demographic factors (age, gender, etc.), life events (Schouten, 2019; Tuzovic \& Kabadayi, 2020); and at the context level: i.e. country's culture (Zheng et al., 2015), economic factors, governmental policy and technology (Tuzovic \& Kabadayi, 2020), perception of well-being and distributive justice in the working environment (Mishchuk et al., 2018). Table 1 portrays the factors ensuring employee well-being at different levels.
Table 1. Factors ensuring employee well-being

\begin{tabular}{l|l}
\hline Level & \multicolumn{1}{c}{ Factor } \\
\hline \multirow{3}{*}{ Organizational } & Work design factors \\
& Manager's behavior and leadership style \\
& Interpersonal relationships \\
& Employees' role in an organization \\
& Work-life balance \\
& Communication \\
& Flexibility \\
& Stress \\
& Intrinsic traits of an employee as a \\
& personality; \\
& Values \\
& Resistance \\
& Health \\
& Emotions \\
& Social-demographic factors \\
Individual & Government policy \\
& Country's economic state \\
& Technological changes \\
& Globalization \\
& Cultural differences and changes \\
\hline Context &
\end{tabular}

During the COVID-19 pandemic, an extensive focus has been put on one of the context factors: social distance (Tuzovic \& Kabadayi, 2020). It should be emphasized that social distance affects the well-being of both employees who cannot maintain it due to their work specifics, and employees who maintain social distance (working from home). Tuzovic and Kabadayi (2020) state: "On one hand, frontline employees who provide "essential" services (health care, grocery stores, pharmacies, long-term care homes, etc.) face increased health risks in terms of infection, stress and mental illness, while, on the other, the sudden shift to work from home and self-isolation is causing unanticipated mental health consequences, such as anxiety, loneliness, and depression, which lead to an increase in substance abuse and even suicide" (Tuzovic \& Kabadayi, 2020, p. 3).

To ensure the safe functioning and well-being of employees, the use of sustainable human resource management practices becomes especially relevant: such practices help organizations attend to the needs of their employees (Abid et al., 2020; Davidescu et al., 2020). In turn, job satisfaction becomes one of the essential constituents of the overall well-being (Cannas et al., 2019). The sustainable human resource management approach that includes the strategic view 
towards the human resources, economic effectiveness, social responsibility, and environmental protection has recently focused on three research themes: economic aspects and sustainable competition; social and environmental health emphasizing the sustainable human resource management practices, relationships between the human resource management and organizational performance highlighting sustainable leadership and sustainable environment (Macke \& Genari, 2019; Linhartova, 2021).

Studies (Guest, 2017; Cooper et al., 2019) reveal the relationship between particular sets of HRM practices and high levels of well-being and positive employment. Well-being-focused HRM practices are especially significant: training and development; mentoring and career support, job design increasing challenges and autonomy; providing information and feedback, positive social and physical environment, employees' voice and organizational support (Guest, 2017). The aforementioned results in positive performance at individual and organizational levels. Therefore, the sustainable approach to the HRM provides mutual benefits to an employee and organization and allows the extensive application of such practices in the activities of organizations.

In the successful application of sustainable HRM practices, extensive attention is put on the trust in an organization, its leaders, and employees. According to researchers, trust significantly influences communication and organizational success (Braun et al., 2013), employee satisfaction, engagement and commitment, individual and organizational performance, and employee well-being (Alfes et al., 2012; Ilyas et al., 2020).

The concept of trust varies among the representatives of different theories. According to the theory of the transactional cost, economists analyze trust as the calculation of benefit or risk minimization (North et al., 2017; Huo et al., 2018). In social exchange theory, sociologists conceptualize trust as a part of relationships between individuals or institutions (Knapp et al., 2020). In finances, agency theory states that trust reduces complexity and insecurity, preventing opportunistic behavior (Styhre, 2016). The resource-based approach emphasizes that reliable human resources ensure a competitive advantage (Hoskisson et al., 2018). However, a significant proportion of scientific literature refers to a generalized definition of trust proposed by Mayer et al. (1995) and Rousseau et al. (1998), which conceptualizes trust as an individual's expectations of others in the hope that they will behave honestly and fairly. Trust emerges from two principal factors: risk and interdependence (Rousseau et al., 1998). Here, the risk is conceptualized as the probability of loss perceived by the trusting party. Interdependence anticipates that the interests of one party cannot be satisfied without the other party. Colquitt et al. (2007), based on Mayer et al. (1995), include benevolence as another principal factor causing trust: individual beliefs that the behavior of the other party will be benevolent or at least not harmful.

To sum up, trust can be defined as one party's attitude towards other party as benevolent and trustworthy partner. Moreover, two significant aspects must be emphasized: individual's intention to accept their vulnerability, and belief that other party will behave favorably to an individual who trusts it (Colquitt et al., 2007). This concept is actively analyzed by scientists in the management field (Mayer et al., 1995; Vanhala \& Ahteela, 2011; Vanhala \& Ritala, 2016; Haynes et al., 2020).

Scientific papers analyzing the concept of trust distinguish two types of trust: interpersonal and impersonal (Vanhala et al., 2016). According to Haynes et al. (2020), interpersonal trust includes trust in colleagues and managers, and impersonal trust includes trust in the organization. Organizational trust includes both interpersonal relationships and impersonal trust. Therefore, it is evident that trust can be analyzed at the organizational, team, and individual levels (Fulmer \& Gelfand, 2012).

Mayer et al. (1995) state that employees, in the context of interpersonal trust, decide whether to trust another party based on three features of another party: ability, benevolence, and integrity (Vanhala et al., 2016; Vanhala, 2019). The abilities of a person who is trusted are defined as skills, competencies, and personal traits that allow the person to perform particular actions in a particular area (Mayer et al., 1995). It is believed 


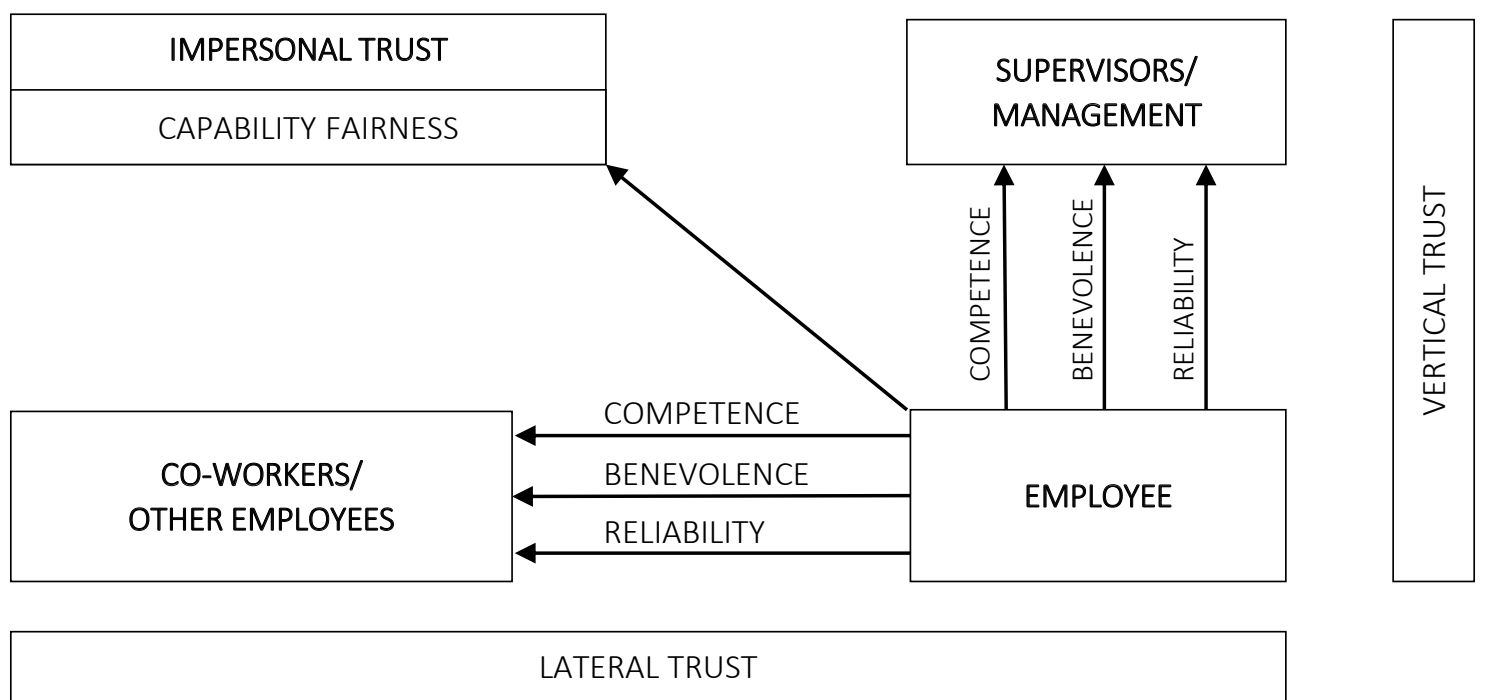

Figure 1. The stucture of organizational trust

that a person possessing integrity (reliability) tends to behave honestly with others (Colquitt et al., 2007).

In contrast, Vanhala and Ahteela (2011) state that employees, in the context of impersonal trust, decide whether to trust in an organization based on two principal organizational aspects: capability and fairness. The capability aspect is related to organization's ability to cope with complex situations, and use resources, management's abilities and practices of decision-making, the organization's technological reliability, sustainability, and market competitiveness (Vanhala \& Ahteela, 2011). The fairness aspect reflects appropriate human resource management practices, honest behavior of the organization's managers, as well as adequate and sufficient communication (Vanhala \& Ahteela, 2011; Okpamen, \& Ogbeide, 2020). According to $\mathrm{Ng}$ (2015), trust in an organization also depends on employees' feelings, worldviews, values, and their evaluation. Behind the emotional components lies a rational reconsideration of information, whether the organization is trustworthy, honest. The goal of any individual is foremost to evaluate the risk whether an organization is worth trust before attaching to it and trusting it (Mehta et al., 2020). Moreover, an employee's trust in an organization majorly depends on the organizational competencies revealed in the long term (Pirson \& Malhotra, 2011) (see Figure 1).

\section{GENERALIZATION OF THE MAIN STATEMENTS}

Based on research on organizational trust, it can be argued that trust is a factor that provides positive outcomes for an organization: employee security, loyalty, commitment, identification with the organization, and others. Therefore, trust in an organization is particularly significant to every organization (Lambert et al., 2020), since it allows one to create relationships between employees, ensure information transfer between different departments, and promotes commitment to follow the organization's positive values and strategy. Employee trust in management and colleagues strengthens the team spirit and team goal achievement (Den Hartog et al., 2002). It should be noted that trust in an organization allows employees to give their work meaning, and, at the same time, influences employee well-being (Alfes et al., 2012).

The literature analysis revealed that recently, studies on employee well-being and organizational trust, as well as on the relationships between these concepts, focused on two areas: 1) the search for direct relationships between well-being and organizational trust in the context of psychological contract; 2) the search for indirect relationships between well-being and organizational trust in the context of social exchange and organizational support theories (see Table 2). 
Table 2. Review of empirical research on the relationship between organizational trust and employee well-being in the context of sustainable HRM

Source: Composed by the authors.

\begin{tabular}{|c|c|c|c|c|c|c|}
\hline Author & $\begin{array}{l}\text { Relationship } \\
\text { type }\end{array}$ & Predictor & Outcome & Mediator & Moderator & Study scope \\
\hline Helliwell \& Huang (2011) & Direct & Workplace trust & Well-being & & & $\begin{array}{l}\text { Employees from Canada and } \\
\text { United States }\end{array}$ \\
\hline Jovanović, (2016) & Direct & $\begin{array}{l}\text { Interpersonal trust and institutional } \\
\text { trust }\end{array}$ & Subjective well-being & & & Serbian adults \\
\hline Anand et al. (2012) & Direct & Job autonomy and trust in leadership & $\begin{array}{l}\text { Commitment to continuous } \\
\text { improvement }\end{array}$ & & & $\begin{array}{l}\text { Employees from health care } \\
\text { organization in Illinois }\end{array}$ \\
\hline Salmi et al. (2020) & Direct & Leadership & Employee well-being & & & $\begin{array}{l}\text { Manufacture company's leaders } \\
\text { and employees in Finland }\end{array}$ \\
\hline Jena et al. (2018) & Direct and indirect & Employee engagement & Organizational Trust & $\begin{array}{l}\text { Psychological well-being } \\
\text { and transformational } \\
\text { leadership }\end{array}$ & & $\begin{array}{l}\text { Executives employed in } \\
\text { multinational service industries } \\
\text { operating in eastern India }\end{array}$ \\
\hline Richter \& Näswall (2019) & Indirect & Job insecurity & $\begin{array}{l}\text { Job satisfaction and mental } \\
\text { health }\end{array}$ & Trust in organization & & $\begin{array}{l}\text { Employees from Swedish } \\
\text { manufacturing companies }\end{array}$ \\
\hline Braun et al. (2013) & Indirect & Transformational leadership & Job satisfaction & $\begin{array}{l}\text { Trust in supervisor and } \\
\text { trust in team }\end{array}$ & & $\begin{array}{l}\text { Employees from Germany } \\
\text { research university }\end{array}$ \\
\hline Hendriks et al. (2020) & Indirect & Virtuous leadership & Work-related well-being & Trust in manager & $\begin{array}{l}\text { Individual leader } \\
\text { virtues and various } \\
\text { characteristics of } \\
\text { subordinates and } \\
\text { organization }\end{array}$ & $\begin{array}{l}\text { Employee form various industries } \\
\text { in UK and the USA }\end{array}$ \\
\hline Vanhala \& Ritala (2016) & Indirect & HRM practices & $\begin{array}{l}\text { Organizational } \\
\text { innovativeness }\end{array}$ & Impersonal trust & & $\begin{array}{l}\text { Employees from forestry and } \\
\text { information and communication } \\
\text { companies in Finland }\end{array}$ \\
\hline Ilyas et al. (2020) & Indirect & Ethical leadership & Employee engagement & Organizational trust & $\begin{array}{l}\text { General } \\
\text { self-efficacy }\end{array}$ & $\begin{array}{l}\text { Employees working in public and } \\
\text { private organizations in Pakistan }\end{array}$ \\
\hline Ullah et al. (2019) & Indirect & Organizational politics & Well-being & $\begin{array}{l}\text { Interpersonal trust at } \\
\text { work }\end{array}$ & & Employees form Pakistan \\
\hline Alfes et al. (2012) & Indirect & Perceived HRM practices & Well-being & & Trust in employer & $\begin{array}{l}\text { Employees and their line } \\
\text { managers in service sector } \\
\text { organization in the UK }\end{array}$ \\
\hline Tsai (2013)... & Indirect & Perceived organizational support & Employee well-being & Social capital & & Employees of hospitals in Taiwan \\
\hline Heyns \& Rothmann, (2018) & Indirect & Trust & Engagement at work & Autonomy & & $\begin{array}{l}\text { Employees from South African } \\
\text { agricultural business }\end{array}$ \\
\hline Paillé et al. (2010) & Indirect & Perceived organizational support & $\begin{array}{l}\text { Intention to leave } \\
\text { organization and } \\
\text { organizational citizenship } \\
\text { behavior }\end{array}$ & $\begin{array}{l}\text { Trust in organization and } \\
\text { satisfaction }\end{array}$ & & $\begin{array}{l}\text { Working adults with French } \\
\text { citizenship }\end{array}$ \\
\hline Yu \& Choi (2014) & Indirect & Corporate social responsibility & $\begin{array}{l}\text { Well-being and firm } \\
\text { performance }\end{array}$ & Organizational trust & & Employees in Chinese firms \\
\hline Eisenberger et al. (2001) & Indirect & Perceived organizational support & $\begin{array}{l}\text { Outcomes: employees' } \\
\text { affective organizational } \\
\text { commitment and job } \\
\text { performance }\end{array}$ & Felt obligation & & $\begin{array}{l}\text { Postal employees form United } \\
\text { States }\end{array}$ \\
\hline Bak (2020) & Indirect & Supervisor behavior (feedback) & Innovative work behavior & $\begin{array}{l}\text { Trust in supervisor and } \\
\text { affective commitment }\end{array}$ & & $\begin{array}{l}\text { Cross-sectional study based on } \\
\text { local government employees in } \\
\text { South Korea }\end{array}$ \\
\hline
\end{tabular}


Researches on the direct relationship between organizational trust and well-being have emphasized positive relationships (Helliwell \& Huang, 2011; Jovanović, 2016; Ullah et al., 2019; Jena et al., 2018). Ullah et al. (2019) have found that increased interpersonal trust led to an increase in employee well-being; however, decreased interpersonal trust led to a decrease in employee well-being. Jena et al. (2018) highlighted the influence of psychological well-being on employees' perceived organizational trust. According to Jena et al. (2018), psychological well-being increases creative thinking and demonstrates positive social behavior; hence, employees feel well and work effectively. It results in strengthening work meaningfulness and a positive impact on organizational trust.

Some authors analyze the relationship between organizational trust and well-being through the psychological contract prism. Richter and Näswall (2019) define organizational trust as a typical characteristic of healthy employer-employee relationships linked to employee well-being. The psychological contact can be damaged when employees perceive that an employer fails to fulfill obligations: does not share information, does not ensure security, etc. In such situations, the employee does not trust organization, which leads to decreased trust in work, lower commitment and weaker psychological well-being (Richter \& Näswall, 2019).

Researchers who analyzed the indirect relationship between organizational trust and well-being examined the links between leadership style, leader's feedback to followers, perceived HRM practices, work autonomy, organizational support, social responsibility, and well-being, mediated by organizational trust.

Studies have found a mediating role of trust in manager in the relationship between manager's transformational leadership and job satisfaction (Braun et al., 2013), virtuous leadership, job satisfaction, and engagement (Hendriks et al., 2020), while trust in a team: in the relationships between team's attitudes towards manager's transformational leadership and job satisfaction (Braun et al., 2013). It has been found that organizational trust had a mediating effect on the relationships between ethical leadership and employee engage- ment (Ilyas et al., 2020). The aforementioned results enriched previous conclusions on the significance of trust at the individual, team (Braun et al., 2013), and organizational levels (Vanhala \& Ritala, 2016). Plausibly, transformational and ethical leadership help team members perceive their trustworthiness, while team members develop a team trust perception. Furthermore, such leaders' actions as sharing information, feedback, and developing a mutual trust with employees, create positive emotions and strengthen both managers' and employees' well-being (Salmi et al., 2020).

In line with the social exchange theory, in return for the trust, employees who trust in their managers and team members, work longer and harder to accomplish goals and not disappoint managers, use their free time to help colleagues, and share information useful in performing tasks. Moreover, when employees feel supported and valued by managers, they exhibit higher loyalty to the organization, maintain symmetry in the employee-employer psychological contract (Vanhala \& Ritala, 2016).

Researchers who analyzed the relationships between perceived HRM practices and well-being (Alfes et al., 2012), and the relationships between organizational policy and well-being (Ullah et al., 2019), concluded that in organizations where HRM practices were focused on high performance, employee well-being was evaluated as low. However, after including moderating variables: trust in employers (Alfes et al., 2012), and mediating variable - interpersonal trust (Ullah et al., 2019), the positive impact of trust in managers and trust in employer on employees' well-being was found. The aforementioned insights are particularly valuable to practitioners responsible for high organizational performance and long-term organizational functioning. In organizations where employees trust in their managers, employee well-being scores are higher in comparison to employees who do not trust in their managers and whose organizations apply performance-oriented HRM practices. It should be noted that when an employee does not trust their manager, HRM practices are less effective in ensuring employee well-being and performance. One of the HRM practices ensuring well-being and performance is job autonomy, which provides individual job meaningfulness: 
employees are more likely to seek meaningful job; therefore, identifying themselves with the job and perceiving contribution to the achievement of the organization's goals (Anand et al., 2012; Heyns, \& Rothmann, 2018).

Studies analyzing the relationships between perceived organizational support and well-being (Tsai, 2013; Paillé et al., 2010) and the relationship between corporate social responsibility and well-being (Yu \& Choi, 2014) have proved that employees who trust in an organization, its support, and believe in the organization's values, exhibit higher levels of security and happiness, which increases employee well-being. Furthermore, it is proved that the high level of corporate social responsibility, including its tools aiming at employees well-being, positively influences the performance of organizations (Myšková \& Hájek, 2019; Gallardo-Vázquez \& Lizcano-Álvarez, 2020) and attractiveness of employer's brand (Bite \& Konczos-Szombathelyi, 2020). Support of employees usually includes various aspects. According to Bak (2020), feedback from a manager can be perceived as organizational support influencing well-being. Furthermore, support can be perceived as access to necessary resources (i.e., technologies, reliable internet connection, and others) in remote work. In the social context, support is related to the roles of a manager, family, friends, and colleagues (Tuzovic \& Kabadayi, 2020). Empathy and shared responsibility between colleagues or family members, as forms of social support, help employees overcome stress caused by social distancing (Abel \& McQueen, 2020). Furthermore, social support can be related to providing financial resources to employees who lose jobs, and therefore offering relief with regard to financial well-being, at least in the short term, which becomes especially relevant during the pandemic. Although the aforementioned support is somewhat significant for employee well-being, studies reveal that it positively influences happiness, and as a result, helps improving physical health and wellness (Tuzovic \& Kabadayi, 2020).

\section{DISCUSSION}

The scientific literature provides evidence of the direct influence of trust on employee well-being (Helliwell \& Huang, 2011; Jovanović, 2016), how- ever, the majority of it focuses on the indirect relationships between the aforementioned concepts (Jena et al., 2018; Alfes et al., 2012; Heyns \& Rothmann, 2018; Yu \& Choi, 2014; Ullah et al., 2019; Hendriks et al., 2020). The indirect relationships are often examined in the context of trust in managers and trust in an organization, exploring the impact of management style on job satisfaction and engagement (Braun et al., 2013; Ng, 2015; Ilyas et al., 2020; Hendriks et al., 2020; Salmi et al., 2020), perceived organizational support-based HRM practices (Tsai, 2013; Paille et al., 2010), social responsibility (Yu \& Choi, 2014), employee well-being or innovative behavior (Alfes et al., 2012; Kowalski \& Loretto, 2017; Vanhala \& Ritala, 2016).

Prior studies revealed that a manager's behavior shaped by a selected management style, together with employees' trust in the manager, ensures employee well-being and associated consequences (Hendrinks et al, 2020; Braun et al., 2013; Ilyas et al., 2020; Bak, 2020). For instance, a manager seeking employees' trust develops empathetic behavior, which positively influences employees' performance and attitudes towards an organization. It should be emphasized that ambiguity often arises when trust in a manager is equated with trust in an organization. As a manager is a member of an organization, the manager's behavior reflects an organization. However, it does not reflect the concept of impersonal trust. Therefore, in the analysis of the influence of management style on employee well-being, trust in a manager shall act as an intermediate variable.

Scientific papers continue ongoing discussions in the context of the organizational support theory, emphasizing that employees' perceptions of organizational support and justice positively influence trust in the organization. Employees generally tend to personalize an organization and develop general beliefs on the extent to which an organization values their contribution and supports their well-being, based on HRM practices used (Eisenberger et al., 2001). Employees experiencing the employer's commitment, respond with their commitment to the employer (Vanhala \& Ritala, 2016), and citizenship behavior (Ryu \& Hong, 2020). 
However, it should be noted that only one type of organizational trust is usually under investigation, while employee well-being is identified to the outcomes of organizational performance without considering subjective and psychological aspects of employees. Furthermore, a significant part of studies did not reveal clear relationships between well-being in an organization and its HRM practices. A somewhat small part of studies analyzed more than one sustainable well-being-focused practice: organizational support, providing information and feedback, and job autonomy. However, as sustainable HR practices help improve employees' skills, ensure dedication to the organization, and support goal achievement, mutual benefits are evident: employees' well-being, and the organization's high performance (Kowalski \& Loretto, 2017; Diaz-Carrion et al., 2018; Lee, 2019). A sustainable HR-based strategy allows the organization to ensure its employees' well-being and develop their trust in the organization and feelings of security (Kozlovskyi et al., 2019).

Organizational trust or both types of trust often act as mediators between HRM practices and well-being-related consequences. The findings are similar in organizations investing in social responsibility-focused HRM practices and organizations investing in perceived organizational support; therefore, it can be assumed that sustainable HRM practices, fulfilling the condition of organizational trust, positively influence employee well-being. The phenomenon of trust is essential for both organizations and employees, enabling the parties to be exposed to certain risks anticipating positive consequences. Hence, HR managers shall take a proactive role in promoting the development of HRM practices, organizational support, and social responsibility.

Based on the analysis of prior studies, it can be stated that the scientific literature lacks the comprehensive approach to the influence of organizational trust on employee well-being. This may be influenced by the fact that scholars have only recently begun to empirically investigate trust in co-workers as the aspect of interpersonal trust. The empirical analysis of three elements of organization trust shall provide an extensive understanding of the influence of or- ganizational trust on employee well-being and employees in general.

It should be noted that the existing empirical evidence is somewhat inconsistent. The existence of different types of trust raises the question of whether an interpersonal or impersonal trust has a more substantial influence on employee well-being. Some scholars state that ensuring trust in managers is essential for employees' feeling good, while others focus on the conclusion that trust in an organization is the most significant aspect of organizational trust. However, neither of the statements has received proper empirical testing. The scientific literature analysis revealed several studies analyzing organizational trust from interpersonal and impersonal trust perspectives to achieve the comprehensive effect (Tsai, 2013; Jovanović, 2016; Vanhala et al., 2016; Haynes et al., 2020). Although the scientific literature includes statements that types of trust are interchangeable, it is suggested that all types of organizational trust are significant in the achievement of the maximum positive impact on employee well-being. The above is evident from the analysis of the influence of different types of organizational trust, which showed that the strongest impact is achieved when comprehensive organizational trust is ensured.

The studies analyzed in this paper prove that trust is essential at the individual, team, and organizational levels. Moreover, the literature analysis has proven that organizational trust has a positive influence at all levels in the achievement of employee well-being and related consequences, such as trust in job, organizational commitment, citizenship and/or innovative behavior. It must be emphasized that the topic received fewer empirical studies at the team level; hence, it is proposed to focus future studies on exploring the relationships between organizational trust and employee well-being at the team level, considering that teams often have a cross-disciplinary nature and consist of representatives of various professions united to achieve a common goal. Furthermore, globalization processes determine the increasing cross-cultural nature of teams; hence, cross-cultural competencies become essential in ensuring smooth socialization processes in an organization. Moreover, this pa- 
per emphasizes the conditions of prior studies: the influence of Western and Eastern cultures on the analyzed phenomena differs significantly. Therefore, this study suggests that future studies exploring in-depth relationships between organizational trust and employee well-being in the context of sustainable HRM shall be compared among different cultures. Besides, the differences among industry sectors are purposeful to explore. Examining the aforementioned conditions is especially relevant for practitioners interested in ensuring organizational trust and employee well-being in a particular organization.
Future studies shall pay attention to identifying the relationships between sustainable human resource practices, well-being, and organizational trust, focusing on the mediating role of the latter and disclosing trust with colleagues as a somewhat less examined type of trust. Moderator analysis is suggested to determine the strength of the influence of organizational trust or its elements on the aforementioned relationships. Such studies allow HRM practitioners and managers to deepen the understanding of an organization's employees and meet their needs in the achievement of high performance.

\section{CONCLUSION}

This paper contributes to expanding knowledge of the links between sustainable HRM practices, employee well-being, organizational trust, engagement, and job satisfaction at the individual, team and organization level. The benefits of sustainable human resource management to organizations are evident as it focuses on essential aspects of the successful functioning of an organization: economic effectiveness, social responsibility, and environmental protection. The literature analysis revealed that sustainable HRM practices that are focused on meeting employees' needs are particularly significant as they positively influence employee well-being. It must be emphasized that ensuring employees' well-being based on sustainable HRM principles stimulates critical thinking, demonstrates positive social behavior, leads to good feelings and effective performance of employees, and increases organizational trust as a vital aspect of smooth organizational performance. Analysis of scientific literature confirmed the direct and indirect relationship between employee well-being and organizational trust; however, such relationships are evident only between particular elements. Consequently, research is needed to distinguish the relationships between sustainable human resource management practices and employee well-being, with the mediating moderating roles of organizational trust, which consists of trust in co-workers, trust in managers and trust in the organization.

\section{AUTHOR CONTRIBUTIONS}

Conceptualization: Vaida Jaskeviciute, Asta Stankeviciene, Danuta Diskiene, Julija Savicke.

Data curation: Vaida Jaskeviciute, Asta Stankeviciene, Danuta Diskiene, Julija Savicke.

Formal analysis: Vaida Jaskeviciute, Asta Stankeviciene, Danuta Diskiene, Julija Savicke.

Funding acquisition: Vaida Jaskeviciute, Asta Stankeviciene, Danuta Diskiene, Julija Savicke.

Project administration: Vaida Jaskeviciute, Asta Stankeviciene, Danuta Diskiene, Julija Savicke.

Resources: Vaida Jaskeviciute, Asta Stankeviciene, Danuta Diskiene, Julija Savicke.

Supervision: Asta Stankeviciene, Danuta Diskiene.

Validation: Vaida Jaskeviciute, Asta Stankeviciene, Danuta Diskiene, Julija Savicke.

Visualization: Vaida Jaskeviciute, Danuta Diskiene.

Writing - original draft: Vaida Jaskeviciute, Asta Stankeviciene, Danuta Diskiene, Julija Savicke.

Writing - review \& editing: Vaida Jaskeviciute, Asta Stankeviciene, Danuta Diskiene, Julija Savicke. 


\section{REFERENCES}

1. Abel, T., \& McQueen, D. (2020). The COVID-19 pandemic calls for spatial distancing and social closeness: not for social distancing. Int J Public Health, 65, 231. https://doi.org/10.1007/ s00038-020-01366-7

2. Abid, G., Ahmed, S., Elahi, N. S., \& Ilyas, S. (2020). Antecedents and mechanism of employee wellbeing for social sustainability: A sequential mediation. Sustainable Production and Consumption, 24, 79-89. https://doi.org/10.1016/j. spc.2020.06.011

3. Alfes, K., Shantz, A., \& Truss, C. (2012). The link between perceived HRM practices, performance and well-being: The moderating effect of trust in the employer. Human Resource management Journal, 22(4), 409427. https://doi.org/10.1111/1748 8583.12005

4. Anand, G., Chhajed, D., \& Delfin, L. (2012). Job autonomy, trust in leadership, and continuous improvement: An empirical study in health care. Operations Management Research, 5(3-4), 70-80. https://doi.org/10.1007/ s12063-012-0068-8

5. Arbatani, T. R., Farhangi, A. A., \& Dadashzadeh, Y. (2016). Framing the Current Challenges and Trends in Human Resource Management. International Journal of Humanities and Cultural Studies (IJHCS). ISSN 2356-5926, 589-600. Retrieved from https:// www.semanticscholar.org/paper/ Framing-the-Current-Challengesand-Trends-in-Human-ArbataniFarhangi/61ba4f525c9f29d0e47eec2de0287b6fa7d5dfb3

6. Bak, H. (2020). Supervisor Feedback and Innovative Work Behavior: The Mediating Roles of Trust in Supervisor and Affective Commitment. Frontiers in Psychology, 11, 1-12. https://dx.doi.org /10.3389\%2Ffpsyg.2020.559160

7. Bernardi, A. (2019). The capability approach and organizational climate as tools to study occupational health and safety.
Insights into Regional Development, 1(2), 155-169. https://doi. org/10.9770/ird.2019.1.2(6)_

8. Bilan, Y., Mishchuk, H., Samoliuk, N., \& Mishchuk, V. (2020). Gender discrimination and its links with compensations and benefits practices in enterprises. Entrepreneurial Business and Economics Review, 8(3), 189204. https://doi.org/10.15678/ EBER.2020.080311

9. Bite, P., \& Konczos-Szombathelyi, M. (2020). Employer branding concept for small- and medium-sized family firms. Journal of International Studies, 13(3), 143-160. https://doi. org/10.14254/2071-8330.2020/13$3 / 10$

10. Boudreau, J. W., \& Ziskin, I. (2011). The future of HR and effective organizations. Organizational Dynamics, 40(4), 255. https://doi.org/10.1016/j. orgdyn.2011.07.003

11. Braun, S., Peus, C., Weisweiler, S., \& Frey, D. (2013). Transformational leadership, job satisfaction, and team performance: A multilevel mediation model of trust. The Leadership Quarterly, 24(1), 270283. https://doi.org/10.1016/j. leaqua.2012.11.006

12. Cannas, M., Sergi, B. S., Sironi, E., \& Mentel, U. (2019). Job satisfaction and subjective well-being in Europe. Economics and Sociology, 12(4), 183-196. https://doi.org/10.14254/2071789X.2019/12-4/11

13. Cleveland, J. N., Byrne, Z. S., \& Cavanagh, T. M. (2015). The future of $\mathrm{HR}$ is $\mathrm{RH}$ : Respect for humanity at work. Human Resource Management Review, 25(2), 146-161. https://doi. org/10.1016/j.hrmr.2015.01.005

14. Colquitt, J. A., Scott, B. A., \& LePine, J. A. (2007). Trust, trustworthiness, and trust propensity: A meta-analytic test of their unique relationships with risk taking and job performance. Journal of Applied Psychology,
92(4), 909-927. https://doi. org/10.1037/0021-9010.92.4.909

15. Compton, W. C., Smith, M. L., Cornish, K. A., \& Qualls, D. L. (1996). Factor structure of mental health measures. Journal of personality and social psychology, 71(2), 406-413. https:// psycnet.apa.org/doi/10.1037/00223514.71.2.406

16. Cooper, B., Wang, J., Bartram, T., \& Cooke, F. L. (2019). Well-being-oriented human resource management practices and employee performance in the Chinese banking sector: The role of social climate and resilience. Human Resource Management, 58(1), 85-97. https:// doi.org/10.1002/hrm.21934

17. Davidescu, A. A., Apostu, S. A., Paul, A., \& Casuneanu, I. (2020). Work Flexibility, Job Satisfaction, and Job Performance among Romanian Employees - Implications for Sustainable Human Resource Management. Sustainability, 12(15), 6086. https://doi.org/10.3390/ su12156086

18. Den Hartog, D. N., Shippers, M. \& Koopman, P. (2002). The impact of leader behaviour on trust in management and coworkers. SA Journal of Industrial Psychology, 28(4), 28-35. https:// doi.org/10.4102/sajip.v28i4.75

19. Diaz-Carrion, R., LópezFernández, M., \& RomeroFernandez, P. M. (2018). Developing a sustainable HRM system from a contextual perspective. Corporate Social Responsibility and Environmental Management, 25(6), 1143-1153. https://doi.org/10.1002/csr.1528

20. Diener, E., Suh, E. M., Lucas, R. E., \& Smith, H. L. (1999). Subjective well-being: Three decades of progress. Psychological bulletin, 125(2), 276-302. http:// dx.doi.org/10.1037/00332909.125.2.276

21. Eisenberger, R., Armeli, S., Rexwinkel, B., Lynch, P. D., \& Rhoades, L. (2001). Reciprocation 
of perceived organizational support. Journal of Applied Psychology, 86(1), 42-51. https://doi.org/10.1037/00219010.86.1.42

22. Fulmer, C. A., \& Gelfand, M. J. (2012). At what level (and in whom) we trust: Trust across multiple organizational levels. Journal of management, 38(4), 1167-1230. https://doi.org /10.1177\%2F0149206312439327

23. Gallardo-Vázquez, D., \& Lizcano-Álvarez, J. L. (2020). CSR-related competitiveness and legitimacy in MSMEs. Economics and Sociology, 13(1), 52-73. https://doi.org/10.14254/2071789X.2020/13-1/4

24. Guest, D. E. (2017). Human resource management and employee well-being: Towards a new analytic framework. Human resource management journal, 27(1), 22-38. https://doi. org/10.1111/1748-8583.12139

25. Haynes, S. H., Leone, M. C., Keena, L. D., May, D. C., Ricciardelli, R., \& Lambert, E. G. (2020). The association between different forms of organizational trust and correctional staff job stress. Journal of Crime and Justice. https://doi.org/10.1080/073564 8X.2020.1734056

26. Heyns, M., \& Rothmann, S. (2018). Volitional trust, autonomy satisfaction, and engagement at work. Psychological reports, 121(1), 112-134. https://doi.org /10.1177\%2F0033294117718555

27. Helliwell, J. F., \& Huang, H. (2011). Well-being and trust in the workplace. Journal of Happiness Studies, 12(5), 747-767. https://doi. org/10.1007/s10902-010-9225-7

28. Hendriks, M., Burger, M., Rijsenbilt, A., Pleeging, E., \& Commandeur, H. (2020). Virtuous leadership: a source of employee well-being and trust. Management Research Review, 43(8), 951-970. https://doi.org/10.1108/MRR-072019-0326

29. Hoskisson, R. E., Gambeta, E., Green, C. D., \& Li, T. X. (2018). Is my firm-specific investment protected? Overcoming the stakeholder investment dilemma in the resource-based view. Academy of Management Review, 43(2), 284-306. https://doi. org/10.5465/amr.2015.0411

30. Huo, C., Zhang, M., \& Ma, F. (2018). Factors influencing people's health knowledge adoption in social media: the mediating effect of trust and the moderating effect of health threat. Library Hi Tech., 36(1), 129-151. https://doi.org/10.1108/LHT-042017-0074

31. Ilyas, S., Abid, G., \& Ashfaq, F. (2020). Ethical leadership in sustainable organizations: The moderating role of general selfefficacy and the mediating role of organizational trust. Sustainable Production and Consumption, 22, 195-204. https://doi.org/10.1016/j. spc.2020.03.003

32. Jena, L. K., Pradhan, S., \& Panigrahy, N. P. (2018). Pursuit of organisational trust: Role of employee engagement, psychological well-being and transformational leadership. Asia Pacific Management Review, 23(3), 227-234. https://doi.org/10.1016/j. apmrv.2017.11.001

33. Jovanović, V. (2016). Trust and subjective well-being: The case of Serbia. Personality and Individual Differences, 98, 284-2880. https:// doi.org/10.1016/j.paid.2016.04.061

34. Khoreva, V., \& Wechtler, H. (2018). HR practices and employee performance: the mediating role of wellbeing. Employee Relations, 40(2), 227-243. https://doi.org/10.1108/ ER-08-2017-0191

35. Knapp, J. R., Diehl, M. R., \& Dougan, W. (2020). Towards a social-cognitive theory of multiple psychological contracts. European Journal of Work and Organizational Psychology, 29(2), 200-214. https://doi.org/10.1080/1 359432X.2019.1709538

36. Kowalski, T. H., \& Loretto, W. (2017). Well-being and HRM in the changing workplace. The International Journal of Human Resource Management, 28(16), 2229-2255. https://doi.org/10.1080 /09585192.2017.1345205
37. Kozlovskyi, S., Grynyuk, R., Baidala, V., Burdiak, V. \& Bakun, Y. (2019). Economic Security Management of Ukraine in Conditions of European Integration. Montenegrin Journal of Economics, 15(3), 137153. Retriwved from https:// ideas.repec.org/a/mje/mjejnl/ v15y2019i3137-153.html

38. Lambert, E. G., Keena, L. D., Haynes, S. H., Ricciardelli, R., May, D., \& Leone, M. (2020). The Issue of Trust in Shaping the Job Involvement, Job Satisfaction, and Organizational Commitment of Southern Correctional Staff. Criminal Justice Policy Review, 1-23. https://doi. org/10.1177/0887403420903370

39. Laužikas, M., \& Miliūte, A. (2020). Human resource management effects on sustainability of high-tech companies: what Lithuania and South Korea can learn from each other. Insights into Regional Development, 2(2), 562-579._https://doi.org/10.9770/ IRD.2020.2.2(5)

40. Lee, H. W. (2019). How does sustainability-oriented human resource management work? Examining mediators on organizational performance. International Journal of Public Administration, 42(11), 974-984. https://doi.org/10.1080/01900692. 2019.1568459

41. Linhartova, V. (2021). Analyzing the Role of Public Expenditures in Human Development: Panel Data Analysis of EU-28 Countries. Montenegrin Journal of Economics, 17(1), 83-94. https://doi. org/10.14254/1800-5845/2021.171.6

42. Macke, J., \& Genari, D. (2019). Systematic literature review on sustainable human resource management. Journal of cleaner production, 208, 806815. https://doi.org/10.1016/j. jclepro.2018.10.091

43. Mayer, R. C., Davis, J. H., \& Schoorman, F. D. (1995).

An integrative model of organizational trust. Academy of management review, 20(3), 709-734. https://doi. org/10.2307/258792 
44. Malyarets, L.M., Barannik, I.O., Sabadash, L.O. Grynko, P.O. (2019). Modeling the Economic Sustainability of the Macro System (for Example Ukraine). Montenegrin Journal of Economics, 14(3), 23-35. https://doi. org/10.14254/1800-5845/2019.153.2

45. Mehta, A. M., Tam, L., Greer, D. A., \& Letheren, K. (2020). Before crisis: How near-miss affects organizational trust and industry transference in emerging industries. Public Relations Review, 46, 101886. https://doi. org/10.1016/j.pubrev.2020.101886

46. Mishchuk H., Samoliuk N., Bilan Y., Streimikiene D. (2018). Income inequality and its consequences within the framework of social justice. Problemy Ekorozwoju, 13(2), 131-138.

47. Myšková, R., \& Hájek, P. (2019). Relationship between corporate social responsibility in corporate annual reports and financial performance of the US companies. Journal of International Studies, 12(1), 269-282. https://doi. org/10.14254/2071-8330.2019/12$1 / 18$

48. Ng, T. W. H. (2015). The incremental validity of organizational commitment, organizational trust, and organizational identification. Journal of Vocational Behavior, 88, 154-163. https://doi.org/10.1016/j. jvb.2015.03.003

49. North, C., O’Donnell, E., \& Marsh, L. (2017). The economics of trust in buyer-seller relationship: a transaction cost perspective. Global Journal of Management and Marketing, 1(1), 81. http://igbr. org/wp-content/uploads/2017/08/ GJMM_Vol_1_No_1_2017. pdf $\#$ page $=85$

50. Okpamen, H., \& Ogbeide, S.O. (2020). Board director reputation capital and financial performance of listed firms in Nigeria. Insights into Regional Development. Insights into Regional Development, 2(4),_765-773._http://doi. org/10.9770/IRD.2020.2.4(3)

51. Orsila, R., Luukkaala, T., Manka, M. L., \& Nygard, C. H. (2011). A new approach to measuring workrelated well-being. International Journal of Occupational Safety and Ergonomics, 17(4), 341-359. https://doi.org/10.1080/10803548. 2011.11076900

52. Paillé, P., Bourdeau, L., \& Galois, I. (2010). Support, trust, satisfaction, intent to leave and citizenship at organizational level. International Journal of Organizational Analysis, 18(1), 41-58. https://doi. org/10.1108/19348831011033203

53. Pirson, M., \& Malhotra, D. (2011). Foundations of organizational trust: What matters to different stakeholders? Organization Science, 22(4), 1087-1104. https:// doi.1287/orsc.1100.0581

54. Ponting, S. S. A. (2020). Organizational identity change: impacts on hotel leadership and employee wellbeing. The Service Industries Journal, 40(1-2), 6-26. https://doi.org/10.1080/02642069. 2019.1579799

55. Prasetyo, P. E., \& Kistanti, N. R. (2020). Human capital, institutional economics and entrepreneurship as a driver for quality \& sustainable economic growth. Entrepreneurship and Sustainability Issues, 7(4), 25752589. https://doi.org/10.9770/ jesi.2020.7.4(1)

56. Ryan, R. M., \& Deci, E. L. (2001). On happiness and human potentials: A review of research on hedonic and eudaimonic well-being. Annual review of psychology, 52(1), 141-166. https://doi.org/10.1146/annurev. psych.52.1.141

57. Richter, A., \& Näswall, K. (2019). Job insecurity and trust: Uncovering a mechanism linking job insecurity to well-being. Work \& Stress, 33(1), 22-40. https://doi. org/10.1080/02678373.2018.146 1709

58. Ryff, C. D. (1989). Happiness is everything, or is it? Explorations on the meaning of psychological well-being. Journal of personality and social psychology, 57(6), 1069-1081. https://doi. org/10.1037/0022-3514.57.6.1069

59. Ryu, G., \& Hong, S. W. (2020). The mediating effect of trust in supervisors in the relationship between constructive performance feedback and perceived fairness of performance appraisal. Public Performance \& Management Review, 43(4), 871888. https://doi.org/10.1080/15309 576.2019.1676274

60. Rousseau, D. M., Sitkin, S. B., Burt, R. S., \& Camerer, C. (1998). Not so different after all: A crossdiscipline view of trust. Academy of management review, 23(3), 393-404. https://doi.org/10.5465/ amr.1998.926617

61. Sakka, G., \& Ahammad, M. F. (2020). Unpacking the relationship between employee brand ambassadorship and employee social media usage through employee wellbeing in workplace: A theoretical contribution. Journal of Business Research. https://doi.org/10.1016/j. jbusres.2020.03.038

62. Salmi, I., Pietiläinen, V., \& Syväjärvi, A. (2020). The Experience Qualities Approach to Leadership and Employee Wellbeing. Nordic Journal of Working Life Studies, 1-22. https://doi. org/10.18291/njwls.122593

63. Schouten, M.J. (2019). Undoing gender inequalities: insights from the Portuguese perspective. Insights into Regional Development, 2, 85-98._https://doi.org/10.9770/ ird.2019.1.2(1)

64. Styhre, A. (2016). Trust versus contracts in corporate governance: agency theory, contractual theory and the fortification of shareholder welfare governance. Management \& Organizational History, 11(3), 276-297. https:// doi.org/10.1080/17449359.2016.1 150859

65. Tamasevicius, V., Diskiene, D., \& Stankeviciene, A. (2020). Human Resource Management Practice in Lithuania: Evidences and Challenges. Montenegrin Journal of Economics, 16(1), 207-226. http://dx.doi.org/10.14254/18005845/2020.16-1.14

66. Tolstyakova, O. V., \& Batyrova, N T. (2020). Strategic management of human resources in modern conditions. Entrepreneurship and Sustainability Issues, 8(2), 
370-382._http://doi.org/10.9770/ jesi.2020.8.2(22)

67. Tsai H. C. (2013). Mediating Impact of Social Capital on the Relationship Between Perceived Organizational Support and Employee Well-being. Journal of Applied Science, 13(21), 47264731. https://dx.doi.org/10.3923/ jas.2013.4726.4731

68. Tuzovic, S., \& Kabadayi, S. (2020). The influence of social distancing on employee wellbeing: A conceptual framework and research agenda. Journal of Service Management. https://doi. org/10.1108/JOSM-05-2020-0140

69. Ullah, S., Hasnain, S. A., Khalid, A., \& Aslam, A. (2019). Effects of perception of organizational politics on employee's well-being: The mediating role of trust and interpersonal conflicts. European online journal of natural and social sciences: Proceedings, 8(1), 1-14. Retrieved from https://europeanscience.com/eojnss_proc/article/ view/5637

70. Van De Voorde, K., Paauwe, J., \& Van Veldhoven, M. (2012). Employee Well-being and the HRM-Organizational Performance Relationship: A Review of Quantitative Studies. International Journal of Management Reviews, 14(4), 391-407. https://doi.org/10.1111/ j.1468-2370.2011.00322.x.

71. Vanhala, M. (2019). Trust as an organizational knowledge sharing enabler - validation of the impersonal trust scale. VINE Journal of Information and Knowledge Management Systems, 50(2), 349-368. https://doi.org/10.1108/VJIKMS-12-2018-0119

72. Vanhala, M., \& Ahteela, R. (2011). The effect of HRM practices on impersonal organizational trust. Management Research Review, 34(8), 869-888. https://doi. org/10.1108/01409171111152493

73. Vanhala, M., \& Ritala, P. (2016). HRM practices, impersonal trust and organizational innovativeness. Journal of Managerial Psychology, 31(1), 95-109. https://doi. org/10.1108/JMP-03-2013-0084
74. Vanhala, M., Heilmann, P., \& Salminen, H. (2016). Organizational trust dimensions as antecedents of organizational commitment. Knowledge and Process Management, 23(1), 46-61. https:// doi.org/10.1002/kpm.1497

75. Viot, C., \& Benraiss-Noailles, L. (2019). The Link Between Benevolence and Well-Being in the Context of Human-Resource Marketing. Journal of Business Ethics, 159(3), 883-896. https://doi. org/10.1007/s10551-018-3834-1

76. Waterman, A. S., Schwartz, S. J., Zamboanga, B. L., Ravert, R. D., Williams, M. K., Bede Agocha, V., ... \& Brent Donnellan, M. (2010). The Questionnaire for Eudaimonic Well-Being: Psychometric properties, demographic comparisons, and evidence of validity. The Journal of Positive Psychology, 5(1), 41-61. https://doi. org/10.1080/17439760903435208

77. World Health Organization. (2010). Healthy workplaces: a model for action: for employers, workers, policy-makers and practitioners. World Health Organization. Retrieved from https://www.who.int/occupational_health/publications/healthy_ workplaces_model

78. Yang, C. (2014). Does ethical leadership lead to happy workers? A study on the impact of ethical leadership, subjective well-being, and life happiness in the Chinese culture. Journal of business ethics, 123(3), 513-525. https://doi. org/10.1007/s10551-013-1852-6

79. Yidong, T., \& Xinxin, L. (2013) How Ethical Leadership Influence Employees' Innovative Work Behavior: A Perspective of Intrinsic Motivation. J Bus Ethics 116, 441-455._https://doi. org/10.1007/s10551-012-1455-7

80. Yu, Y., \& Choi, Y. (2014). Corporate social responsibility and firm performance through the mediating effect of organizational trust in Chinese firms. Chinese Management Studies, 8(4), 577592. https://doi.org/10.1108/CMS10-2013-0196

81. Zhang, X., Lin, Z., Liu, Y., Chen, X., \& Liu, D. M. (2020). How do human resource management practices affect employee wellbeing? A mediated moderation model. Employee Relations: The International Journal, 42(4), 90. https://doi.org/10.1108/ER-082019-0320

82. Zheng, X., Zhu, W., Zhao, H., \& Zhang, C. (2015). Employee wellbeing in organizations: Theoretical model, scale development, and cross-cultural validation. Journal of Organizational Behavior, 36(5), 621-644. https://doi.org/10.1002/ job. 1990 